\title{
Clinicohematological profile of hemolytic anaemia in tertiary care hospital in rural Andhra Pradesh
}

\author{
Anusha $\mathbf{R}^{1}$, Sravanthi N.L ${ }^{2}$, Vijayalakshmi ${ }^{3}$ \\ ${ }^{1}$ Dr. Anusha Raavi M.D. ${ }^{2}$ Dr. Nalluru Lakshmi Sravanthi M.D. Assistant Professor, NRI Medical College, ${ }^{3}$ Dr. Vijaya \\ Lakshmi. M.D., Professor, NRI Medical College, Mangalagiri road, Guntur, Andhra Pradesh, India. \\ Address for correspondence: Dr.Nalluru Lakshmi Sravanthi, Email: glsravanthi@ gmail.com
}

\begin{abstract}
Introduction: Hemolytic anaemias are a group of disorders that cause significant morbidity in children. Method: A cross sectional study was conducted at NRI Medical College for a period of 1 year. All cases of newly diagnosed and old cases of hemolytic anaemia on follow up were included. Results: The study showed beta thalassemia as the most common hemolytic anaemia; followed by malaria, sickle beta thalassemia, thalassemia intermedia, beta thalassemia minor, Sickle cell disease, sickle cell trait, auto immune hemolytic anaemia, and hereditary spherocytosis. The mean hemoglobin at presentation was $5.39 \mathrm{gm} / \mathrm{dl}$. Anthropometric measurements in 32 cases of congenital hemolytic anaemias revealed height $<3^{\text {rd }}$ centile in 9 cases. Weight less than $3^{\text {rd }}$ centile was seen in 11 cases. 13 children had hemolytic facies. Massive splenomegaly causing discomfort, gall stones, heart failure were seen in 2 cases each. In thalassemia major, 10 cases required frequent transfusions, [10-12 per year]. 9 came for less frequent transfusions [6 per year]. Sickle thalassemia, thalassemia intermedia, required one transfusion every 1-2 years. Occasional transfusions were given in sickle cell anaemia, hereditary spherocytosis. Serum ferritin levels varied between 220-1427. Conclusion: Hemoglobin electrophoresis remains the main investigation of choice in diagnosis of hemolytic anaemia. Thalassemia major is the most severe among other hemolytic anaemias encountered in this series. The study emphasizes the need to improve awareness regarding hemoglobinopathies among population, prenatal screening, blood transfusion policies, chelation policies to prevent complications in transfusion dependent patients.
\end{abstract}

Keywords: Clinicohematological profile, Growth failure, Hemolytic Anaemia, Thalassemia, Rural Andhrapradesh

\section{Introduction}

Hemolytic anaemia result when rate of destruction of RBCs exceed the capacity to produce RBCs [1]. Hereditary hemoglobin disorders are the most commonly encountered single gene disorder in India [2]. Inherited RBC defects of structure and metabolism may result in chronic hemolysis state that include hemoglobinopathies like sickle cell anaemia, alpha thalassemia, beta thalassemia, RBC enzyme defect like G6PD, RBC membrane disorder like hereditary spherocytosis [3]. Malaria is highly endemic in India, presents as hemolytic anaemia with breakdown of RBCs. The mean age of presentation of homozygous thalassemia is 6 months. Splenomegaly occurs in thalassemia and increase the anaemia [4]. The only form of treatment available for thalassemia patients are regular transfusions, iron chelation therapy in an selected cases [5].

Manuscript received: $14^{\text {th }}$ April 2016

Reviewed: $26^{\text {th }}$ April 2016

Author Corrected; $11^{\text {th }}$ May 2016

Accepted for Publication: $24^{\text {th }}$ May 2016 attempt to prevent iron overload and judicious use of splenectomy in cases complicated with hypersplenism. Marrow transplantation also has an important role in The present study attempts to reveal the clinical and hematological profile of patients with different types of congenital hemolytic anemia admitted in a teretiary care hospital of Guntur, Andhra Pradesh. Review of literature shows only few epidemeological studies particularly in this part of the country, though the disease is fairly prevalent. We undertake this study with this idea.

\section{Materials and Methods}

This cross sectional study was carried out in a tertiary care hospital at Guntur over a period of one year. Prior to initiation of study, ethical clearance was obtained. All patients admitted in the indoor of department of pediatrics between age group of 3 months to 12 years with evidence of hemolysis were included in the study. Infants less than 2 months and children $>12$ years were 
excluded from the present study. Infants were excluded to rule out Rh mediated hemolytic disease of newborn. 41 cases were included in the study after obtaining written informed consent from parent or guardian. Age at onset of disease, presence of pallor, jaundice, requirement of blood transfusions was recorded. History regarding consanguinity was taken. Physical examination included anthropometric measurements such as height, weight, hemolytic facies, jaundice, liver size, spleen size were recorded.

\section{Investigations}

- Hemoglobin estimation, total count, platelet count, was done using standard guidelines.
- Hemoglobin electrophoresis was done on agarose gel at PH 8.6.

- Serum total bilirubin was measured with autoanalyser.

- Estimation of serum ferritin was estimated by ferrizimic test system.

- Ultrasonography of abdomen was done to detect organomegaly, gall stones or any other abnormality.

- X ray of skull was taken for crew cut appearance.

- Rapid test for malaria test were done in all cases.

- Data was analyzed with appropriate statistical methods.

\section{Results}

A total of 41 cases of hemolytic anaemia were included in the study.

Table 1: Prevalence of types of hemolytic anaemia in the present study $(n=41)$.

\begin{tabular}{|l|c|c|}
\hline Type of Anaemia & Number & \% \\
\hline 1. Beta thalassemia major & 19 & 46 \\
\hline 2. Malaria & 9 & 21.9 \\
\hline 3. Sickle beta thalassemia & 4 & 9.7 \\
\hline 4. Thalassemia intermedia & 4 & 9.7 \\
\hline 5. Thalassemia minor & 1 & 2.4 \\
\hline 6. Sickle cell disease & 1 & 2.4 \\
\hline 7. Sickle cell trait & 1 & 2.4 \\
\hline 8. AIHA & 1 & 2.4 \\
\hline 9. Her spherocytosis & 1 & 2.4 \\
\hline
\end{tabular}

Table 1 shows that the commonest hemolytic anemia in the present study is beta thalassemia major (19) followed by malaria (9), sickle beta thalassemia (4) thalassemia intermedia (4), one each of sickle cell disease, sickle cell trait, AIHA, hereditary spherocytosis, thalassemia minor.

Table 2: Distribution of hemolytic anaemia according to sociodemographic variables.

\begin{tabular}{|c|c|c|c|c|c|c|c|c|c|}
\hline Diagnosis & $\begin{array}{c}\text { Beta } \\
\text { thalassemia } \\
\text { major }\end{array}$ & $\begin{array}{l}\text { Sickle beta } \\
\text { thalassemia }\end{array}$ & $\begin{array}{l}\text { Thalassemia } \\
\text { intermedia }\end{array}$ & $\begin{array}{c}\text { Thalassemia } \\
\text { minor }\end{array}$ & $\begin{array}{c}\text { Sickle } \\
\text { cell } \\
\text { disease }\end{array}$ & $\begin{array}{c}\text { Sickle } \\
\text { cell } \\
\text { trait } \\
\end{array}$ & AIHA & $\begin{array}{c}\text { Hereditary } \\
\text { spherocyto } \\
\text { sis } \\
\end{array}$ & Malaria \\
\hline \multicolumn{10}{|c|}{ Sex } \\
\hline Females & 10 & 1 & 1 & 0 & 0 & 1 & 0 & 0 & 3 \\
\hline Males & 9 & 3 & 3 & 1 & 1 & 0 & 1 & 1 & 6 \\
\hline \multicolumn{10}{|c|}{ Family history } \\
\hline Yes & 2 & 0 & 0 & 0 & 0 & 0 & 0 & 1 & 1 \\
\hline No & 17 & 4 & 4 & 1 & 1 & 1 & 1 & 1 & 8 \\
\hline \multicolumn{10}{|l|}{ Age group } \\
\hline $1-3$ years & 7 & 0 & 0 & 0 & 0 & 0 & 0 & 0 & 1 \\
\hline 4-6 years & 7 & 0 & 3 & 0 & 1 & 1 & 1 & 0 & 2 \\
\hline $7-9$ years & 3 & 0 & 1 & 0 & 0 & 0 & 0 & 0 & 2 \\
\hline $9-12$ years & 2 & 4 & 0 & 1 & 0 & 0 & 0 & 1 & 4 \\
\hline
\end{tabular}

From table 2, it is evident that male to female incidence is $0.9: 1$ in thalassemia major. Family history is positive in $2 / 19$ cases of thalassemia major and one case of hereditary spherocytosis. History of consanguinity was seen in 14 cases of all 
congenital anemias. History of similar complaints in siblings was seen in 4 cases. Death of sibling with similar complaints was seen in one case of thalassemia major. The maximum numbers of children were in age group range of 1-6 years in thalassemia major. In the present study, growth retardation was seen in cases of thalassemia major, weight less than $3^{\text {rd }}$ centile was seen in 11/19 cases. Of these, 6 were in age group 5-8 years, 3 cases in ages 9-12 years, 2 cases 1-4 years. Height less than $3^{\text {rd }}$ centile was seen in 9 cases, among these children, 5 were in age group of 5-8 years, 3 in age group of 9-12 years, 1 case in 1-4 years. On general examination, pallor was seen in 38 cases (93\%). The mean hemoglobin was least in thal major followed by thal intermedia, sickle thalassemia and thalassemia minor. Majority of cases $78.04 \%$ presented with a hemoglobin \% of $4-8 \% .14 .63 \%$ of cases presented with Hemoglobin less than 4 gm $\%$, $7.3 \%$ presented with Hemoglobin $8-12 \mathrm{gm} \%$.

Table 3: Hematological profile of study population.

\begin{tabular}{|c|c|c|c|c|c|c|c|c|c|}
\hline \multicolumn{2}{|c|}{ Diagnosis } & $\begin{array}{c}\text { Beta } \\
\text { thalassemia } \\
\text { major }\end{array}$ & $\begin{array}{c}\text { Sickle } \\
\text { thalassemia }\end{array}$ & $\begin{array}{c}\text { Thalassemia } \\
\text { intermedia }\end{array}$ & $\begin{array}{c}\text { Thalassemia } \\
\text { minor }\end{array}$ & $\begin{array}{c}\text { Sickle } \\
\text { cell } \\
\text { trait }\end{array}$ & AIHA & H.S & malaria \\
\hline $\begin{array}{c}\text { Hb } \\
\text { Gm/dl }\end{array}$ & mean & 4.1 & 6.2 & 4.2 & 6.7 & 8.2 & 4.6 & 6.4 & 6.32 \\
\hline & S.D & 1.009 & 0.46 & & & & & & 1.24 \\
\hline $\begin{array}{c}\text { Serum } \\
\text { ferritin }\end{array}$ & mean & 1427.8 & & & & & & & \\
\hline & S.D & & & & & & & & \\
\hline \multirow{2}{*}{$\begin{array}{c}\text { SSB } \\
\text { mean }\end{array}$} & 3.1 & 2.7 & 2.3 & 1.6 & 1.1 & 2.2 & 1.8 & 2.9 \\
\cline { 2 - 10 } & S.D & 1.2 & 0.5 & & & & & & 1.15 \\
\hline \multirow{2}{*}{$\begin{array}{c}\text { Retic } \\
\text { count }\end{array}$} & mean & 7.2 & 7 & 3 & 3 & 2 & 5 & 7 & 4.16 \\
\cline { 2 - 10 } & S.D & 3.2 & 2.4 & & & & & 0.75 \\
\hline
\end{tabular}

Serum ferritin levels were done in 13 cases of thalassemia major. Mean serum ferrritin was $1427 \mathrm{ng} / \mathrm{ml}$; chelation was started in 5 cases. Icterus was seen in 36 cases. Mean TSB was highest in thalassemia major (3.1) followed by sickle thalassemia, thalassemia intermedia, thalassemia minor. Mean TSB of malaria was 2.9. Mean HbF was highest in thalassemia major with $72.5 \%$, followed by thalassemia intermedia (46) and sickle thalassemia (29.45). HbS was highest in sickle cell disease $(88 \%)$, followed by sickle thalassemia $(60.4 \%)$, sickle cell trait $(24 \%)$.

Table 4: Clinical Profile.

\begin{tabular}{|l|c|c|c|c|}
\hline Diagnosis & Jaundice & Hepatomegaly & Splenomegaly & Cardiac \\
\hline Thalassemia major & 18 & 15 & 19 & 2 \\
\hline Sickle thalassemia & 4 & 1 & 4 & 0 \\
\hline Thalassemia intermedia & 2 & 0 & 2 & 0 \\
\hline Sickle cell disease & 1 & 0 & 0 & 0 \\
\hline HS & 1 & 1 & 9 & 0 \\
\hline Malaria & 8 & 9 & 9 & 0 \\
\hline
\end{tabular}

Splenomegaly was seen in all cases of, Thalassemia major, sickle thalassemia, thalassemia, hereditary spherocytosis. speen $>6 \mathrm{~cm}$ was seen in 15 cases. Massive splenomegaly causing abdominal discomfort was noted with 2 cases. Splenectomy was undertaken in one case. Hemolytic facies was noted in 13 cases of thalassemia major. X ray of skull showed crew cut appearance in 4 cases of thalassemia major. Death occurred in 2 cases of complicated malaria. All children received routine immunizations except one, special vaccines were administered in 7 cases.

\section{Discussion}

Hemoglobinopathies are of worldwide occurrence. Though some geographical areas have high prevalence in India, average frequency of sickle cell gene is around $5 \%$. Highest frequency reported in Orissa 9\%, Assam $8.8 \%$, Madhya Pradesh $7.4 \%$, Uttar pradesh7.1\% $[6,7,8]$. The distribution of beta thalassemia is not uniform in Indian subcontinent.
Highest frequency of beta thalassemia trait is reported in Gujarat $10-15 \%$, followed by Sindhis $10 \%$, Punjab $6.5 \%$, Tamil nadu and Maharashtra $[9,10,11,12,13,14]$. In the present study, 41 cases of hemolytic anaemia between ages 6 months- 12 years have been studied. The commonest congenital hemolytic anemia was beta thalassemia major(19), sickle beta thalassemia(4), thalassemia intermedia(4), thalassemia minor(1). 
Commonest acquired causes of hemolytic anaemia was malaria (9). The study by Shivashankara et al [15], a hospital based family study, showed commonest hemolytic anaemia as beta thalassemia (15), thalassemia trait (20), 2 cases of sickle cell trait, 1 case of sickle cell thalassemia .Preethi et al [16] another hospital based study noted thalassemia major most common -23 cases, followed by sickle cell anaemia- 5 cases, sickle trait 1 case, HS in 4 cases. The male to female incidence was 0.9. Unlike other studies, our study showed more females than males. Male preponderance was seen with chatopadhyay [17], preethi et al [16].

In the present study, consanguinity was seen with 15 cases of hereditary hemolytic anaemia which is similar to preethi et al $(55 \%)$. This suggests the possibility of individual spontaneous mutations and or high prevalence of thalassemia gene. Beta thalassemia major accounted for 19 cases (46\%).16 cases had onset $<1$ year, similar to preethi et al [16]. Hemoglobin varied between 3-8.2 [16]. peripheral smear showed predominantly microcytic hypochromic picture, reticulocyte count varied from 4-18\%. Mean (7.2) preethi et al described 5-15\%. Bone marrow examination revealed erythroid hyperplasia in all cases, $\mathrm{Hb}$ electrophoresis revealed means $\mathrm{HbF}$ 72.52. Mean HbA2 was 2.3. Serum bilirubin was elevated in all cases mean 2.8. 10 of these required frequent 10-12 transfusions, 9 required 6-8 transfusions. Growth was affected in $55.5 \%$ males, $60 \%$ males. Growth retardation became evident after the age of 5 years. Most of the children who were wasted and stunted belonged to low socioeconomic status. The difference between thalassemics and their normal siblings was evident after the age of 5 years. Similar growth retardation was seen with Anitha Saxena [18], growth faltering was seen in $75 \%$ of thalassemic patients obvious after the age of 8 years. Study by Kirti Grow [19] showed growth faltering as the most common complication of thalassemia major. The reasons for growth retardation could be due to hypoxia, iron overload, compounded by undernutrition, and low SES. Other complications encountered were raised serum ferritin, massive splenomegaly causing discomfort in 2 children, hemolytic facies in 13 cases, untreated anaemia presenting in heart failure in 2 cases. Endocrine complications were not evaluated. In the present study, there were 4 cases of sickle thalassemia. Male to female ratio was $3: 1$. mean $\mathrm{Hb}$ was 6.2 , serum bilirubin was 2.7 , and retic count was $7 \%$. Splenomegaly was seen in all cases. They required one transfusion yearly or once in 2 years. Their $\mathrm{Hb}$ electrophoresis revealed mean $\mathrm{HbF} 29.45$, mean $\mathrm{HbA} 2$
3.7, mean HbS 60.4. No growth retardation was seen in these children. No complications were noted. There were 4 cases of thalassemia intermedia. Onset was more than 2 years; They required transfusions yearly to once in two years. Mean $\mathrm{Hb}$ was 4.2 , TSB was 2.3. $\mathrm{Hb}$ electrophoresis revealed $\mathrm{HbF} 46 \%, \mathrm{HbA} 2$ was $6 \%$. No complications were noted in these children. Similar results were seen with Seema Tyagi et al [20].

There was a case of thalassemia minor male, mean $\mathrm{Hb}$ was 6.8 , TSB was 1.6 ,retic count was 3 . HbA2 was $4.5 \%$. He did not require any transfusions. There were no complications. One case of sickle cell anaemia was admitted with $\mathrm{Hb}$ of 4.7 , reticulocyte of $8 \%$. HbS was $88 \%$. Peripheral smear revealed sickle cell along with normal cells. Clinical manifestations were benign requiring occasional transfusions. Painful crises were occasionally seen. 1 case of hereditary spherocytosis was seen, with $\mathrm{Hb} 6.4$, retic count $7 \%$, requiring occasional transfusions. There were no cases of enzyme defects such as G6PD or pyruvate kinase as screening tests for detecting enzyme defeciencies were not done. Malaria was the most common acquired hemolytic anaemia with $\mathrm{M}$ : F ratio 2:1, with mean $\mathrm{Hb} 6.3$, TSB 2.9. peripheral smear showed falciparum ring forms, gametocytes in 4 cases, plasmodium vivax trophozoites in 3 cases, and combined vivax and falciparum infection in 2 cases. Hypoglycemia (RBS $<60 \mathrm{mg} \%$ ) was seen in 5 cases of complicated malaria. Splenomegaly was seen in all cases. Rapid tests for parasite antigen were positive in all cases death occurred in 2 cases of complicated malaria.

\section{Conclusion}

Though there is lot of useful hematological investigations for the diagnosis of hemolytic anaemias, we conclude that $\mathrm{Hb}$ electrophoresis clinches the diagnosis in hemoglobinopathies. Of the prevalent hemoglobinopathies, beta thalassemia major follows a more severe course as compared to other hemolytic anaemias encountered in this series. The impact of genetic diseases, in particular hemoglobinopathies (thalassemia and sickle cell anaemia) on global mortality and morbidity especially in developing countries, world health organization has urged its member states to implement comprehensive national integrated programmes for prevention and management of thalassemia and other hemoglobinopathies. There is scope for improvement and further activities like awareness raising, screening for carriers, premarital screening, antenatal diagnosis, need to be undertaken.

\section{Source of Support: Nil, Conflict of Interest: None} Permission of IRB: Yes 


\section{References}

1. Kliegman MR, Stanton BF, St geme WJ, Shor NF. Nelson text book of pediatrics $20^{\text {th }}$ edition:Elsevier publications;2016.

2. Weatherall DJ, Clegg JB: The thalassemia syndromes, $4^{\text {th }}$ edition: Oxford Blackwell scientific publications;2001.

3. Surhone LM, Tennoe MTHenssonow SF, Congenital hemolytic anaemia, Saarbrucken, Germany: VDM Verlog, Dr.Muller ;2010.

4. UNICEF: The state of worlds children oxford: Oxford university press; 1996.

5. Yasish HM- Thalassemia: http://www.emedicine. com/PED/topic2229.htm; Accessed $23^{\text {rd }}$ oct 2002.

6. Modell B, Berdoukas V. The clinical approach to Thalassemia: London:Gruns and Stration;1984.

7. La Nasa G, Caocci G, Argiolu F, Giardini C, Locatelli F, Vacca A, Orofino MG, Piras E, Addari MC, Ledda A, Contu L. Unrelated donor stem cell transplantation in adult patients with thalassemia. Bone marrow transplantation. 2005 Dec 1;36(11):971-5.

8. Verma IC, Choudhry VP, Jain PK. Prevention of thalassemia: a necessity in India. Indian journal of pediatrics. 1992 Nov 1;59(6):649-54.

9. Manglani M, Lokeshwar MR, Vani VG, Bhatia N, Mhaskar V. 'NESTROFT'--an effective screening test for beta thalassemia trait. Indian pediatrics. 1997 Aug;34(8):702-7.

10. Wild BJ, Bain BJ. Investigations of abnormal hemoglobins and thalassemia. In:Lews Sin, Bain BJ, Bates I, Dacie and Lewis practical hematology, $9^{\text {th }}$ edition, London Curchill Livingstone:2001;231-68.

11. Balgir RS. The burden of hemoglobinopathies in India and the challenges ahead. Curr sci. 2000 Dec 10;79(11):1536-47.
12. Balgir RS. Spectrum of hemoglobinopathies in the state of Orissa, India: a ten years cohort study. JAPI. 2005 Dec;53:1021-6.

13.Balgir RS. The genetic burden of hemoglobinopathies with special reference to community health in India and the challenges ahead. Indian J Hematol Blood Transfus. 2002;20(1):2-7.

14. Varawalla NY, Old JM, Sarkar R, Venkatesan R, Weatherall DJ. The spectrum of $\beta$-thalassaemia mutations on the Indian subcontinent: the basis for prenatal diagnosis. British journal of haematology. 1991 Jun $1 ; 78(2): 242-7$.

15. Shivashankara AR, Jailkhani R, Kini A. Hemoglobinopathies in Dharwad, North Karnataka: A hospital-based study. J Clin Diagnostic Res. 2008;2:593-9.

16. Preethi BP, Monika K, Maitreyee DS, Rashmi K. A hospital based study of Hereditary Hemolytic Anaemias in Davanagere district of Karnataka, India. Bangladesh journal of medical science. 2010 Jan 1;9(3):154.

17. Chattopadhyay $\mathrm{K}$, Biswas $\mathrm{R}$, Bhattacherjee $\mathrm{S}$, Bandyopadhyay R. An epidemiological study on the clenico-hematological profile of patients with congenital hemolytic anemia in a tertiary care hospital of Kolkata. Indian J. Prev. Soc. Med. 2012 Oct;43(4):373.

18. Saxena A. Growth retardation in thalassemiaassemia major patients.Int .J . Human Genet.2003.3(4):237-46.

19. Grow K, Abrol P,Vasist M. Associated complications in beta thalassemia patients. IOSR Journal of pharmacy. 2013. Feb 3(1):22-25.

20. Tyagi S, Kabra M, Tandon N, Saxena R, Pati HP, Choudhry VP. Clinico-haematological profile of thalassemia intermedia patients. International Journal of Human Genetics. 2003;3(4):251.

\section{How to cite this article?}

Anusha R, Sravanthi N.L, Vijayalakshmi. Clinicohematological profile of hemolytic anaemia in tertiary care hospital in rural Andhra Pradesh. Int J Pediatr Res 2016;3(5):303-307.doi:10.17511/ijpr.2016.i05.06 